\title{
$\Omega$ ThelTLAS \\ Epistemological Awareness and Transdisciplinary Attitude: Experiencing the Embodied Being
}

\author{
Enrique Vargas Madrazo ${ }^{1}$ and Irmgard Rehaag ${ }^{2}$, Centro EcoDiálogo, Universidad Veracruzana, México, \\ Email: ${ }^{1}$ gaiaxallapan@gmail.com, ${ }^{2}$ irehaag@gmx.net
}

doi: $10.22545 / 2012 / 00023$

\section{E} pistemological-ontological fundamentals and their application in the Community of Learning at the Eco-Dialogue Center is the principal topic in this chapter. The reflections are based on recognizing that wisdom and knowledge cannot be attained in the absence of the body, since the latter provides the stage for the physical-emotionalmental-spiritual articulation for our being and knowing. Through transdisciplanary re-learning based on the development of emotional-cognoscitive abilities, personal, communitary and planetary sustainability becomes possible.

Keywords: body-being, experiential learning, evolutionary learning communities, planetary crisis, deep dialogue, human sustainability.

\section{Introduction}

The present text attempts to reflect a vision of what constitutes the fundamentals of the theory of knowledge or epistemology and their praxis corresponding to our Learning Community (a group of students, academics and people form the surrounding communities) at the Eco-Dialogue Center of the University of Veracruz. The experience of constantly becoming aware of thinking and experience processes resulting from being in community, and from a con- nection with what happens in the life is what we call "Epistemological Awareness". This does not refer to a doctrine, a body of theoretical concepts, but to an attitude that can be expressed as livingis-knowing, suggesting that there is no separation between my knowledge and my process of being alive which means a way of being present and becoming in the world we have been co-creating together for the past ten years.

Our Learning Community, formally, is an academic program dedicated to promoting life long and formal education for sustainability. It has its place within a public state University whose objective is the formation of professional human beings at the service of Veracruz and Mexican Society, in order to collaborate in the co-construction of a Mexico with equity and a satisfactory and sustainable quality of life.

Because we gather and work in this academic center with the vision of collaborating in education for sustainability and care of the community and the environment, it has behooved us to create reflective settings, dialogs and concepts that appropriately reflect these principles through the programs, projects and academic products that we share with our University community, as well as with the society of Veracruz and Mexico in general. 
Under these premises, we will attempt to express simply the articulation of notions and concepts that constitute the center of what we might call our epistemological and ethical fundamentals in work and in life.

\section{Epistemological and Ontological Basis of Our Proposal}

The wisdom and knowledge for a return to the living and present world benefits from an inclusion of a bodily perspective, as noted by Merleau-Ponty for instance; such a perspective is required for the comprehension and articulation (physical-emotionalmental-spiritual) of our being and knowing (we call this the "embodied mind"). In the academic practice of our Center, we propose the study and practice of Embodied Being as it becomes and develops in its community and its world, and thus builds itself through its being and doing in its territory (a pedagogy of place) and its life. It is in the Embodied Being where the mind and the emotions, reflection, poetry and the cognizance of our history and experience in life take place. The recognition of this internal-external ecology (the self and the environmental aspects of our mental processes) of our mind, constitutes the fundamental element for the "ecologizing of knowledge" on a personal and planetary level. It is in this setting where the generation of epistemological awareness as the operative basis for the methodology of knowledge, goes beyond the limits of disciplinarity and interdisciplinarity. We call this proces "transdisciplinary re-learning". We believe that this academic theory and practice is the very basis to co-create means of sustainable living, which are produced and experienced from one instant to the next, from my individuality that at the same time is community and place.

\section{Origins of Our Mind-body Separation in the Western Tradition}

In most of the world, and very particularly in our Mexico and our America, life under the postmodern, globalized cosmovision builds and reiterates itself constantly during our coexistence through an obstreperous omnipresence of the still dominant rationalistic-mechanistic vision of the world. We swim and live in the sea of modernity and postmodernity to the extent that we never notice it, nor does it move us to conscious reflection; we simply construct our world in its midst. It is so crushing and it has entered our lives so unceasingly that most of the time we are no longer aware that we exist, think, consume, love and die in it...

If we aspire to reconstruct our being such as to create a more sustainable world, we must become conscious and re-appropriate our modern forms of thinking and living in order to reunite them with ancestral forms in a constant retro-progressive (taking what is meaningful from the past and what can create a possible humanity for the future), co-creative act of new sustainable life.

The great paradigm of the West, which erects a way of life founded upon certain forms of thinking is sustained by rationalistic Cartesian thought which has conceived reality - the world- as an object that is independent of whoever observes it and "knows" it (Berman [1]; Capra [2]). This marks a separation between two entities: one that analyzes studies and ultimately prescribes or emits a judgment, and the other that is analyzed, studied and exposed to scrutiny. The reflection of this deterministic manner of conceiving reality is perceptible in the universalistic derivations resulting from the human break with nature, which occurred in the Occident at the dawn of modernity; its roots con be found in the Greece of Plato and Aristotle, in the confines of patriarchal society, Eisler [3], and it expresses itself clearly in the Platonic and Cartesian separation of mind and body, Griffin [4]. Rene Descartes (1596-1650), in his Discourse of Method, Descartes [5], divides the human being into a thinking part - the mind, the soul-, contrasted with the material part - the body-. He considers mentality as the essential part, since its existence does not depend on anything material. The body, which is where the emotions, the passions and instinctive life are expressed, is placed in a subordinate position and its activity is canalized by the thinking part. As Morris Berman states:

For Descartes, the identification of human existence with pure reasoning, the idea that man can know everything that he is given to know by means of his reasoning, included the supposition that mind and body, subject and object, were radically unmatched entities. Apparently, thinking separates me from the world confronting me. I perceive 
my body and its functions, but 'I' am not my body, Berman [1]:270.

In this way, the subject has been separated from its surroundings, thereby conceiving the existence of a universe out there which functions according to mechanical laws that need to be discovered, known and, if possible, controlled. Thus has the essence of the modern human being been constructed: an individuality resting upon an entity "I") that perceives, is informed, conceives, thinks and transforms reality, including the body in the very first place.

This has given rise to the "reflexive I" and the blossoming of the platonic vision in which the 'truth' is purely abstract... Life, then, no longer resides at the horizon, on the rocks, in the air, Vasquez Rengifo [6]. Magic is dead. So now we find ourselves free to plunder the earth, Abram [7]. Consequently knowing is conceived as a rational, logical and mechanical act, carried out by an abstract and aseptic mind, which operates independently of the whole body (Keleman [8]; Damasio [9]).

We can realize an experience of self-inquiry so as to give more life to this reflection. Let us close our eyes and feel the presence of "our body", of our breathing... let us pause there for at least a minute, at the same time perceiving and contemplating our being-breathing, our bodily weight, on being seated on a chair, on the ground, on our Earth. Let us keep our attention simultaneously on these two aspects of our being and becoming for at least a minute now let us ask ourselves: What is our body? To whom does our right hand belong? Who is naming and "thinking" of my hand? Something tells me that my hand belongs to my mind and I tend to "think" that this mind has a place, which happens to be my head... Immediately I think of my brain. However, the very act of saying "I tend to think" or "my brain" suddenly shows that this quality of thinking also "perceives and is conscious" of "my brain". Then we notice that seemingly this "mind" lives outside at a higher level or different from all of my body, including my brain. At this point I can no longer distinguish whether I "think" because in this way I have learned to conceive of myself since childhood, because in this way I tend "to think of myself" as a modern human being, or whether there are other ways of perceiving myself.

At the same time, if I keep the question open and become aware again on my breathing and on my bodily weight and more still if I expand my attention to the skin and muscles of my right hand, maybe I can perceive that consciousness also exists there, that also I-am-hand... Can I feel more than just an object-hand, a part of my being that also has the quality of being present, maybe of biomechanical, sensorial or immunological intelligence? Is this feeling the beginning of an expansion and embodiment of my mind returning to its place of being in my body? What do the cognitive sciences, the studies of consciousness, quantum physics, neurobiology, the perception of art and the traditional systems of knowledge have to say in this respect? Is this vision of a separation of mind and body sustainable?

\section{I am-think-hand-body...}

Let us keep this question and self-inquiry open...

Let us continue with our story of returning to a Being-Mind-Body-that-lives-onthe-Earth...

From this dualism, the "body" operates as a source of metabolic and operative "resources" for a "thinking" brain that computes the mental processes (a metaphor which perfectly matches that of the brain as machine); therefore body and mind are thought as separate entities in the process of knowing. Thus, the act of knowing is an exclusive, characteristic of reason, disembodied, that is devise of any subjective and affective component (Damasio [9]; Maturana [10]; Maturana and Varela [11]). Thus separated from experience, the creation of knowledge based on abstract theoretical systems, mechanical and deterministic models that provide but little insight to the complexity of reality, takes place. That is how we construct and live in the abstract, rational world that we experience as the system of ideas and concepts on which our thinking is based. Much as we try to dissuade ourselves, we are unable to break away from this experience that informs us of a mind computing and ordering, according to concepts, the "world out there" of which the body with its senses informs us.

As far as we know, Plato was the first to propose clearly the separation of the sphere of ideas from the rest of human existence, particularly from corporality (subsistence and sexuality), Griffin [4]. Since in Greek society the woman was associated with domestic reproduction and with carnal and reproductive sexuality (as opposed to the erotic love 
with a young man idealized by Plato, or a "platonic love"), it appears that she was not considered as a part of rational and significative humanity, separated from and rising above nature. That it is that patriarchal society idealizes and privileges the notions of rationality, liberty, and transcendence over nature. Both nature and woman are perceived as chaotic and disorderly entities to be dominated and put in order through reason, Plato's "logos" (not necessarily the only possible acception of this notion!). Another important characteristic associated with woman and nature by mechanistic rationalism is the absence of intelligence and her constant and limiting passivity and receptivity. Nature is only an inane source of matter and energy (the Res Extensa of Descartes); it is the rational man with his logos that imbues her with sense and intelligence, attributes that have to be watch over and rectified constantly. The logos, then, must be superior to that which it governs and dominates. Francis Bacon explained this patriarchal position toward nature in operational and technological terms: nature must be tortured, cornered and compelled by means of meticulous rational and mechanical procedures to reveal her secrets to us, Berman [1]. Patriarchal Christianity incorporated these central elements of separation between body and soul, carnality and divinity into its cosmogony. Nevertheless, the material world con never be eradicated (just like sin); consequently said materiality has to be repressed by the logos, individually and in society as well as in the interaction between humanity and nature.

This cosmogony was founded in Greece in a society based on war for the conquest and domination of other peoples. The individual, nature and life, then, are without intrinsic and sacred value, since it is by imposing death and domination that the state and the powerful classes perpetuate themselves. Susan Griffin confirms the existence of a psychological pattern common to all forms of oppression; said pattern insists on identifying emotion, the body and nature with the feminine gender, these attributes being considered as inferior to reason, the mind and culture, which are identified with masculinity, Griffin [4].

From the eco-psychological viewpoint, this process of establishing patriarchy also produces an equally devastating catastrophe: our being is separated from the world and from the intimacy of our humors, secretions, rhythms and animalities; almost all of our profound connections with nature and the archetypi- cal forms of perceiving them are cut off and declared unrighteous, Glendinning [12]. This should enable us to understand how, in modern society, we humans spend more than $99 \%$ of our lives in a state of indifference to the wild natural world. We become beings whose relationship with nature is constantly influenced by a multitude of ideas and preconceptions, by machines and an artificial way of life, Cohen [13].

At the same time and in a complementary manner, scientific knowledge has developed fragmentarily since the $16^{\text {th }}$ century, thereby resulting in an ever-growing specialization of disciplines that divides and departmentalizes the knowledge generated in the different areas of specialization; this creates a type of knowledge that advances by fragmenting, separating, observing, analyzing, abstracting and controlling. By experiencing modernity in our everyday lives, we realize that this way of confronting the world provides us with comfort, predictability, health and material technological wellbeing. But we are also aware of living in an uncontrolled avalanche of destruction and exhaustion (devastation of the earth, its bio-diversity and cultural diversity, violence, addictions, polarization, etc.) which no one can even conceive, much less contain and convert into something human and sustainable.

\section{Reincarnating Our Living and Knowing in the World}

On the academic level, we now realize that this form of rationalistic-reductionist thinking and transforming the world conforms the disciplinary structure of the universities, which generates forms of knowledge that are closed and incapable of contending with the uncertainty and hyper-complexity of the real world. It is clear that we need knowledge capable of creating pertinent, systemic, sustainable and participative alternatives to meet the crisis which faces the civilized world of today (Morin [14]; Leff [15]; Gadotti [16]; Nicolescu [17]).

Gregory Bateson, Edgar Morin and Basarab Nicolescu have reflected upon the roads that have led us into this entanglement of the reductionism and dualism that prevail in modern thought, particularly in the academic research of universities (Morin [18]; Bateson and Bateson [19]; Nicolescu [17]). These thinkers pose the necessity of a reform in thought that places the human being, the being-that-knows, in the center of knowledge. At the same time, Latin 
American thinkers such as Leonardo Boff, Humberto Maturana and Paulo Freire emphasize the pertinence of human life to an Embodied Being, a Community Being and an Earthly Being. This impels us toward an internal ecology of the thinking subject co-determined and existing within the living ecology of an articulated, organic, non-mechanical world (the auto and the eco posed by Edgar Morin). What is required is to re-edify and co-edify a Human Being-in-the-World that is aware and conscious of the suppositions involved in her or his thoughts and actions, and in his or her experience of knowing.

In agreement with what has been discussed in the present text, this cannot occur through reasoning; rather, it must take place within the totality of our emotional being, within the Reflective and Thinking Embodied Being rooted in a community and in the world in which it lives, articulated and co-determined. According to our experience, is impossible to enter the ambit of complexity by means of just rational thought, even this article which attempts to de-construct rationality, is no more that a representation, a map of ideas about a multiphonic reality inaccessible to the isolated rational mind (Griffin [4]; La Chapelle [20]; Gadotti [16]). One way of escaping from this vicious circle is by opening oneself and experiencing transformation through an awareness that articulates sensations, sentiments, personal experiences, including ritual and wildness (occurring from within an oikos, a community and a world) setting in which we can reconstruct our psyche in a sentient and thinking embodied being, La Chapelle [20].

The experience of constant becoming aware of thinking process resulting from my being in community and from a connection with what happens and is the product of my living in the world is what we call "Epistemological awareness". The Batesons use the word Epistemology with a capital "E" so as to think of it as the systemic "ecology of the mind", Bateson and Bateson [19], implying that every process of the world that is "a difference that produces a difference" is a mental process, and consequently participates co-creating a web of communication and transformation processes. Based on this, we can perceive the world and the human participation in it as constant flow of interacting meanings, an "Epistemology," life in a world in constant computation, Morin [14].

But what are the significance and implications of this work and this epistemological awareness? We wish to make a pause here to describe some aspects of the matter.

We consider that in academic knowledge, and in education and modern life in general, the corporal and emotional cognitive implications involved in this need for an epistemological and cosmological change in regard to complex thought and the transdisciplinary attitude, are commonly subestimated. However, this embodiment of knowledge cannot be realized through the rational and aseptic discourse as a divorce between mind and body. Emotion, pleasure, pain, the capacity to perceive beauty, but above all to create it by articulating our body-mindspirit, cannot be simulated: it must be exercised and experienced.

Although we can emit a discourse from our chair, it continues to be just that; a discourse disconnected from our body and our reality. It is necessary to reconstruct our personal history, to give it new meaning through our Biology of Knowing (Maturana and Varela [11]; Varela et al. [21]), of our total body, being aware of our dualistic rationalizations.

The articulating and inclusive origin of ecological wisdom makes no distinction among art, science, technology, religion, pleasure, or ritual. Unfortunately, even if we become empathic and perceive the pertinence of this vision of the world, transforming rationalistic words and customs into actions, to a life directed by intuitive intelligence, is a leap that can be perceived and embodied only in praxis, by letting the body live in a different, articulated and sacred manner. This participative co-construction of the knowledge filled with experience-based requires a "spelling out of sensations," a complex (which means interconnected and distributed) learning and thinking process that propitiates the articulation of experiences and knowing styles where participative and planetary knowledge originates - inquiry in the first-person of plural-, Heron [22].

\section{Transdisciplinary Re-Learning for Personal, Community and Planetary Sustainability}

In this way, it is possible to cultivate emotionalcognoscitive abilities by elaborating a setting for a dialogue of knowing styles, work with Mother Earth (eco-formative horticulture), rituals and myths, participative processes (community politics for a sol- 
idary society). This will facilitate a blending of sensations in which odors, touch, sounds, sight and taste, stories, family knowledge styles, the encounter of community and personal experiences through cyberspace, etc., are contrasted within a complex framework (complexus) which takes place in our Learning Community at the EcoDialogue Center and beyond, in our Bio-Region and the Planet Earth, which is our living space.

Obviously, we cannot converse peaceably and creatively with someone we desire to dominate and conquer (be it a body, my emotionality, an "object of study" or a human being with whom I live). A conqueror has never been able to know and enjoy the delicious pleasures and secrets that make up the subtle story of the "dominated" peoples. It is logical, then, for our techno-scientific acts to be so coarse, ugly, and inefficient on both local and planetary levels. We perform them behind nature's back, without listening to her subtle whispers, without time to lose, and always thinking of the next conquest to be achieved. For this reason we require a constant process of experiencing a return to the world, of knowing it by conversing with it. That is the personal, communitarian and global experience we create and re-create constantly at the EcoDialogue Center and which, from the academic point of view, we call Transdisciplinary Re-Learning.

In this respect Transdiciplinary Re-Learning sets out from problematization of complexity. It reevaluates the role of intuition, imagination, sensitivity and the body in the processes of generating and acquiring knowledge. Transdisciplinary Re-Learning is a form of learning for the purpose of multiplying and diversifying knowledge through dialogue, for self-transformation, self- knowledge, and for producing "a new art of living", Falconar [23]. All of these qualities make up a set of abilities appropriate for an ecologized knowledge, having epistemological and practical sensitivity for acquiring pertinent social and planetary knowledge. It is designed to open the levels of perception towards the multiple dimensions of Reality, to mobilize the emergence of general intelligence: curiosity, creativity, and reflection (Morin [14] and [24], Morin et al. [25]), and in this respect, to generate processes of social self-organization destined to guide the evolution of consciousness toward the construction of world citizenship, Morin [24].

The central praxis in this process is built starting from the Biology (or Life) of Knowing (Maturana and
Bloch [26]; Maturana and Nisis [27]; Maturana and Verden-Zoller [28]); this proposal starts out from the notion that the process of learning through care (care of my knowing process, care of my body, of my emotions, of my community, of the world) is the essence of the biological-social-spiritual nature of human beings and of all living things. Knowning-is-being, living-is-knowing-what-it-is-to-be. And given that our being has come forth from a unique cognitivecorporal experience (our ontogenetic self-organizing path), our knowing is unique, so we can co-create a world by knowing it. This can be applied to the separation of being and knowing, an idea that arose through Cartesian rationalism. Diverse studies have shown that if the "information" perceived by our organism is not processed and interpreted with all of the body besides the brain (the skin, internal organs, muscles, bones, etc.), the process of "thinking" is meaningless to our being. The emotional environment represented structurally by the "limbic brain" is fundamental and without a substitute in the formation of consciousness (Berman [1]; Damasio [9]). This helps us to realize that ancient expressions such as "feeling butterflies in the stomach", "a broken heart", "think with the stomach", etc., express something more than mere "images"; they are representations profoundly related to the nature of our thinking in our whole being.

Knowing, then, is keeping a "world at hand" (Maturana and Varela [11]; Varela et al. [21]), this in reference to the multidimensional experience of living through the bio-psych-social-spiritual dimensions in the process of knowing, the "whole person leanring" process, Heron [22]. In other words, the cognitive process unfolds through the articulating integrity of the EXPERIENCE of our Embodied Being (Damasio [9]; Maturana and Varela [11]; Varela et al. [21]). The Spanish philosopher Xavier Zubiri called this process "sentient intelligence", Zubiri [29]; correspondingly, the pedagogues, Candida Moraes and Saturnino de la Torre come up with a notion they name sentipensar (feel-think), Torre and Moraes [30]. Indeed, our emotional system constitutes an element that is essential for our kowing to exist and to be meaningful (Damasio [9]; Maturana [10]; Maturana and Varela [11]; Varela et al. [21]).

Thus, in the EcoDialogue Center we place special importance on the personal and collective processes of caring for the emotional world and its correlation with the transformation of reality, no through 
therapeutic processes but through participative settings in which the Circle of the Word, the process of co-learning (learning as a collective participative process) and the spaces of deep dialogue, Bohm [31] operate as participative processes for healing and for personal and communitarian re-learning. In the flow of our emotions, of that story and those doings that we shall now call emotioning of our experience, in the here and now of the present moment, is where we synthesize our evolutionary history as a specie (in the evolutionary chain of which we are part, phylogenetic self-organizing path) and, at the same time, as individuals living in a specific historical space and time (ontogenic self-organizing path), Maturana and Varela [11]. But our everyday experience of knowing what we are living and experiencing is what constructs us cerebrally and corporally as living, cognizant being. In other words, we co-produce what we are and what we know, whereas that which we co-produce and the world in which we live (our time-space environment) produce us (Morin [14], Nicolescu [17]).

\section{Tenderness, Incarnated Knowing Styles and Sustainability}

This space-time "world" is strongly marked by the relationship between the external space of effectivity and the internal space of affectivity, and vice versa. By effectivity we understand the open and communicative process in which the person participates in the life processes, while at the same time being aware of the constraints, the necessities and restrictions of a co-created reality. When this participation is carried on in a sustainable way, i.e. the whole system is improved or at least maintained for a long term, we call this intervention effective. By affectivity, we understand that the participative process expresses and cares about the emotional essence and necessities of the person and her or his community (values, traditions, tenderness, love, beauty, etcetera). The paradigms of the Western world favor efficiency (sort term and mechanistic) over affectivity (and effectivity too), since affectivity has no mercantile or apparently useful value and is therefore neglected and ignored. The reflection of this imbalance is perceptible in the overvaluing of the masculine by the patriarchal, which is understood as being associated with effeciency and the depreciation of the feminine associated with affectivity. It should be made clear that the gender of human beings is no directly connected with worldly masculinity or femininity, but the need for equilibrium leads us to a marriage between the femininity and the masculinity of the world, and within each person, Nicolescu [17]. Achieving this dynamic equilibrium requires a social feminity that can create social ties among human beings, as well as to re-create the sort of wisdom capable of building sustainable futures.

Faced by this situation, what this hyper-modern society immersed in a planetary crisis needs is a profound restatement of our relationship concerning feminization on one hand, and the reconstruction of what is masculine on the other (affective and effective masculine). This relational transformation involves our body, genders and, in the center, our relationship with nature.

This re-enchantment permits us to delve more deeply into our techo-scientific work so as to conduce it toward wisdom that does not classify and dissect nature or social and community processes, but lives and moves as one more of the beings it has created and reared, Vasquez Grimaldo [6]. In this involved and compassive good deed it is possible to rediscover alternative and complementary principles, for example, the line, the dot and the circle, which are the central ancestral elements of mechanical, linear and rational engineering (Bartholomew [32]; Zajonc [33]), in order to apply they in promoting a dialogue of knowing styles, indispensable for sustainable knowledge and designs. A human observer re-inserted into nature, dialoguing through natural processes, can experience forms of organization, proportions and dynamics that are more complex and articulating, more sensitive to the multiple levels of reality than those we presently assume to be the only valid ones, in accord with modern science. The Chinese, with their Taoist and Buddhist science and technology, have produced an almost infinite repertoire of techno-scientific creations that are not based on empirical and rationalistic methodologies, and this tells us of a pluri-epistemology, Needham [34]. In many ways we can point to this style of knowledge as co-creating together with nature through a "feminine" techno-science, in which intuition, empathy and spelling out sensations play a fundamental role in the process of thinking. It is, then, through this kind of re-enchanted and eco-poetic (embedded in community and planet) kind of work that we can redirect our civilization toward a life in commu- 
nities where people live together and with nature, co-creating the ritual of the "art of proportionality", Illich [35].

The process of self-organization and self-creation (the so-called auto-poiesis), Maturana and Varela [11], from our experience have shown to be the foundation for the biological and social processes of life, and consequently of our Transdisciplinary ReLearning Community. It is this cognitive, epistemic systemic, bodily-mental, ecological and planetary reconstruction of the human being that constitutes the essence of transdisciplinary re-learning and the dialogue of knowing styles. Therefore, the constant creation and re-creation of knowing styles, based on epistemological awareness, constitutes the fundamental systemic competence in the process of teaching-learning at the EcoDialogue Center.

It is in this complex dynamic of the Embodied Being where the permanent process of knowing our knowing, of the self, of acting and of living together, takes place through the so-called Biology of Love, i.e., the epistemological awareness that operates within the wholly integrated Human Being (Maturana [10] Maturana and Bloch [26]; Maturana and Nisis [27]; Maturana and Verden-Zoller [28]). This cognoscitive and conscious reconstruction at all the levels, becomes articulated with the creative cycle of personal community-social transformation that constitutes our work.

Thus, by means of complex thinking and the biology of knowing and loving, we are pointing up the necessity of co-generating processes of Transdisciplinary Re-Learning and Eco-Literacy, whose four pillars are centered on the process of learning to know, learning to do, learning to live together and learning to be, Nicolescu [17]. All this implies a praxis of re-learning by which living is recognized as a learning process, one that takes place within the somatic process by personally experiencing selfeco healing. Healing through the reconstruction of communitarian creative capacity. It is a question of generating processes requiring active participation, in which research and learning are directed toward the communities with which we collaborate and toward society in general.

With this object in mind, we start from the methodological proposal to retake the notion of Evolutionary Learning Communities (ELC), systems of local and alternative learning that seek to catalyze the social transformation toward the creation of sus- tainable and evolutionary futures (Laszlo [36]; Atlee and Zubizarreta [37]). The ELC are places for reevaluating all the spheres of knowledge accessible internally and externally to all those participating in the experience-workshop. In these spaces a profound systemic dialogue takes place (Bohm [31]; Checkland [38]) it starts out from the seed proposal of each educative experience, eventually moving toward the set of local learning elements available within the collectivity of teachers-students-invited participants: texts, videos, poetry, oral knowledge, field experience, student's personal histories, introspection, Falconar [23], sensitive observation of the environment (Barab [39]; Bowers [40]; Clinebell [41]), vernacular research among the peasantry' (Núñez [42]; Vasquez Rengifo [6]), systemic inquiry, Checkland [38], cooperative inquiry, Heron [22], etcetera.

In tune with Morin's Method [18]: "...there is no path walker, the path is made by walking it", Machado [43], the ELC do not reject error, doubt or contradiction; nor they consider the particularities of local knowing styles as impediments to knowledge. These settings for re-learning do consider the perturbations, problems and stories of each participant in the knowing process, or the conflicts within the community as factors of enrichment in the researchaction process. Thus, from the systemic focus we see "the crisis as opportunity" or "the crisis as bifurcation", Laszlo [36], [44]; Prigogine [45]; the imbalances of the general human ecology in its different levels (physiological, mental-emotional, family, economic, inter-generational, community, cultural pathology, etc.) become stages for co-creative work in the ELC (Laszlo [44]; Atlee and Zubizarreta [37]).

The design of the ELC implies the creation of settings where people can co-learn about the interconnected nature of our world, feel the ecological impact of our individual-collective elections and the satisfaction of finding significant ways of contributing to the emergence of sustainable and evolutionary futures. We call this the process of eco-literacy, that is, the awareness needed for re-inserting human processes into an ecosphere and a general ecology, including the ecology of mind(s), an ecologizing of the life of each person and of the community through the experience of crisis as a co-creative opportunity. These processes are implemented at the heart of a framework of re-education (the constant creation of nourishing settings in which to learn from and for life) of the community for its constant reconstruc- 
tion.

Learning is to establish a conversation with what occurs in nature. This is accomplished under a premise agreed upon by our community in consensus: that of doing weekly work in our gardens with our Mother Earth, taking care of our cultivated plants and letting them take care of us (horticulture and eco-literacy).

By expanding beyond a teaching that only assumes a rational apprehension of information a data, in the sense of grasping something mentally (an action does no result from an order that operates from the brain to the senses), what can emerge is the dialogue of knowing styles, the space of conversation that is established between feeling and the world within a community of learning. From what has been said, the recreation of a practice done with others does not produce an exclusive relation with knowledge but rather with wisdom; thus, the activity resulting, is not derived from an individual volition but from community action, that is, from the reciprocal raising in which the educators become re-created through the action of cultivate.

\section{References}

[1] Berman, M., 1981. The reenchantment of the world. Cornell University Press, Ithaca, New York.

[2] Capra, F., 1996. The web of life: a new scientific understanding of living systems. HarperCollins, London.

[3] Eisler, R., 1996. Sacred Pleasure: Sex, Myth, and the Politics of the Body. Harper, San Francisco.

[4] Griffin, S., 1978. Woman and nature: the roaring inside her. Harper \& Row, New York.

[5] Descartes, R., 1960. Discourse on Method and Meditations. The Liberal Arts Press, New York.

[6] Vasquez R.G., 2003. La Enseñanza es Estar Contento: Educación y Afirmación Cultural Andina. PRATEC Ed. Lima.

[7] Abram, D., 1996. The Spell of the Sensuous: Perception and Language In a More-Than-Human World. Vintage Books, New York.

[8] Keleman, S., 1985. Emotional anatomy. Center Press, Berkeley, California.

[9] Damasio, A.R., 1999. The Feeling of What Happens: Body and Emotion in the Making of Consciousness. Harcourt, New York, New York.
[10] Maturana, H., 2000. El sentido de lo humano. Editorial Ensayo Dolmen, Santiago.

[11] Maturana, H., and Varela, F., 1987. Tree of knowledge: the biological roots of human understanding. Shambhala Publications, Boston.

[12] Glendinning, Ch., 1994. My name is Chellis \& I'm in recovery from western civilization, Shamabala, Boston.

[13] Morin, E., 1999a. El Método III. El Conocimiento del Conocimiento. Ed. Cátedra, Madrid.

[14] Leff, E., 1998. Saber ambiental: sustentabilidad, racionalidad, complejidad, poder. Siglo XXIPNUMA, Cd. México.

[15] Gadotti, M., 2002. Pedagogía de la Tierra. Siglo XXI, Cd. México.

[16] Nicolescu, B., 2002. The manifesto of transdisciplinarity. SUNY Press, New York.

[17] Morin, E., 2001. El Método I. La naturaleza de la naturaleza. Cátedra, Madrid.

[18] Bateson, G., and Bateson, M.C., 2004. Angels Fear: Towards An Epistemology Of The Sacred. Hampton Press, NJ.

[19] Lachapelle, D., 1995. Sacred land, Sacred Sex, rapture of the deep. Concerning Deep Ecology and Celebrating Life. KIVAKI, Asheville, NC.

[20] Varela, F., Thompson, E., and Rosh, E., 1999. De cuerpo presente. Ed. Gedisa, Barcelona.

[21] Heron, J., 1995. Co-operative inquiry: reasearch into de human condition. Sage Publications Ltd, London.

[22] Falconar, T., 2000. Creative intelligence and selfliberation. Korzybsky, non-Aristotelian thinking and Eastern realization. Crossing Home Publishing, Garland, Texas.

[23] Morin, E., 1999b. La cabeza bien puesta. Ed. Nueva Visión, Buenos Aires.

[24] Morin E., Roger C.E., and Motta, R., 2003. Educar en la era planetaria. Ed GEDISA, Barcelona.

[25] Maturana, H., and Susana, B., 2000. Biología del Emocionar y Alba Emoting. Editorial Ensayo Dolmen, Santiago.

[26] Maturana, H., and Nisis, S., 2002. Transformación en la convivencia. Editorial Ensayo Dolmen, Santiago. 
[27] Maturana, H., and Verden-Zoller, G., 2003. Amor y juego. Fundamentos olvidados de lo humano. J. C. Sáez Editor, Providencia, Chile.

[28] Zubiri, X., 1980. Inteligencia sentiente. Inteligencia y realidad. Ed. Alianza, Madrid.

[29] Torre, S.dela., and Moraes, C., 2005. Sentipensar: fundamentos y estrategias para reencantar la educacin. Ediciones Aljibe, Málaga.

[30] Bohm, D., 1996. On Dialogue. Routledge, London.

[31] Bartholomew, A., 2003. Hidden nature: The startling insights of Viktor Schauberger. Adventured Unlimited Press, Stelle, IL.

[32] Zajonc, A., 1997. Meditation as Contemplative Inquiry, Lindisfarne Books, Great Barington, MA.

[33] Needham J., 1954. Science and Civilisation in China. Cambridge University Press, Cambridge.

[34] Illich, I., 1974. Energy and Equity. Marion Boyars Publishers, London.

[35] Laszlo, E., 1996. The system view of the world. A Holistic Vision for our Time. Hampton Press, Cresskill, NJ.

[36] Atlee, T., and Zubizarreta, R., 2003. The Tao of Democracy. Using co-intelligence to create a world that works for all. The writer's Collective, Crangston, Rhode Island.

[37] Checkland, P., 1981. Systems thinking. systems practice. J. Wiley, Michigan.

[38] Barab, S., 1999. "Ecologizing Instruction Through Integrated Units", Middle School Journal, September. National Middle School Association, Westerville, $\mathrm{OH}$.

[39] Bowers, C.A., 2001. Educating for Eco-Justice and Community. The University of Georgia Press, Athens, GA.

[40] Clinebell, H., 1996. Ecotherapy: Healing ourselves, healing the Earth. Fortress Press, Minneapolis.

[41] Núñez M.C., 2005. Ejido, caña y café. Ed. Universidad Veracruzana Xalapa, Ver.

[42] Machado, A., 1940. Poesas completas. Espasa Calpe, Buenos Aires.

[43] Laszlo, E., 2004. Science and the Akashi field. An integral theory of Everything, Inner Traditions, Rochester, VT.

[44] Prigogine, I., 1997. The End of Certainty, Free Press, Washington, DC.

\section{About the Author}

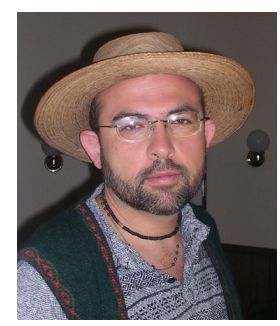

Dr. Enrique Vargas Madrazo Coordinator of the EcoDialogue Center. Founder and Director of the Systemic Biology Academic Area at the Biological Research Institute. He graduated in Biochemistry at the University of La Habana, Cuba, and his Master in Science and Ph.D. at the National University of Mexico (UNAM). During the 90's his scientific research was focused on the molecular evolution of the antibodies and the history of the concept of biological and molecular specificity. Currently his work and life interests are centered on transdisciplinary re-learning process, voluntary simplicity, deep ecology and bioregionalism. Sustainability and the care of the Mother Earth are always the guide that nourish my work.

\section{About the Author}

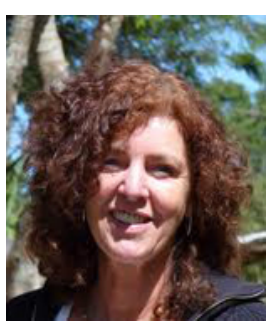

Dr. Irmgard Rehaag Social Worker by the University of Applied Science, Dsseldorf. She has a Master degree in Pedagogy at the University of Westfalia, Mnster, and PhD. in Educative Sciences at the University Johann Wolfgang Goethe Frankfurt/Main. Her research work includes studies on intercultural and multicultural processes in student mobility and systemic approaches for education. She was collaborating as part of the academic staff of the Masters degree of Transdisciplinary studies for sustainability during the years 2007-2010. At the present she is a full time professor at the EcoDialogue Station.

Copyright (c) 2012 by the authors. This is an open access article distributed under the Creative Commons Attribution License (https://creativecommons.org/licenses/by/4.0/), 
which permits unrestricted use, distribution, and reproduction in any medium, provided the original work is properly cited. 